\title{
Hvorfor stemmer russerne på Putin?
}

Bernhard L. Mohr

Oslo: Cappelen Damm 2017

242 sider. ISBN 9788202514259

Omtalt av Thea Hilding [forskningsassistent, Norsk Utenrikspolitisk Institutt, theah@nupi.no]

Et spørsmål som lenge har forundret og interessert vestlige kommentatorer og eksperter på russisk politikk er hva det er som giør at Russlands president Putin beholder sin særdeles høye popularitet i den russiske befolkningen, på tross av landets utvikling i ikke-demokratisk retning. I løpet av Putins regjeringstid har det blant annet blitt vedtatt flere lover som innskrenker forsamlings-, ytrings- og bevegelsesretten for borgerne. Siden Russlands annektering av Krim i mars 2014 har likevel andelen av befolkningen som uttrykker sin støtte til Putin kotinuerlig vært på over åtti prosent. I sin bok Hvorfor stemmer russerne på Putin? søker Bernhard L. Mohr å finne noen svar på nettopp tittelspørsmålet.

Mohr har selv førstehånds erfaring fra Russland, både fra sin studietid, og gjennom et arbeidsopphold for Schibsted-konsernet, i forbindelse med at de i 2006 hadde kjøpt aksjemajoriteten i den på daværende tidspunkt mest leste gratisavisen i St. Petersburg, Moj Rajon («Min bydel»). Mohr omtaler denne tiden som en klondyke-tid for russisk økonomi, hvor man for første gang så utviklingen av en russisk middelklasse. Det er fra denne middelklassen Mohr har sine venner og bekjentskaper fra sin periode i Russland, og det er disse som utgjør flertallet av intervjuobjektene i boken. Bakgrunnen for boken er opplevelsen Mohr har av at mange av hans tidligere kollegaer - som han opplevde som velutdannede og liberale medlemmer av middelklassen - nå ser ut til å uttrykke støtte til det regimet de tidligere kritiserte så sterkt. Han reiser derfor tilbake ti år etter forrige lengre opphold for å snakke med sine tidligere kolleger, forstå hva som har skjedd siden sist, og på den måten være bedre stilt for å besvare spørsmålet om hvorfor russere i så stor grad støtter en mann som har sittet med makten i nesten to tiår.

Boken er lagt opp rundt intervjuene Mohr har gjort med sine tidligere kolleger og har tematiserte kapitler som tar for seg forskjellige forklaringsfaktorer for $\mathrm{Pu}$ tins popularitet: fra historie og ideologi til propaganda, mediekontroll og korrupsion. For å ramme inn intervjuene reflekterer Mohr over det han hører, og gir kontekst med andre fageksperters analyser av samme temaer. Slik blir boken en slags samtale mellom Mohrs egne refleksjoner, hans intervjuobjekter, og eksperter som forsøker 
å forstå seg på dagens Russland. Dette gir Mohrs prosjekt tyngde, og gjør boken både engasjerende i formen, lettlest og lærerik.

Likevel blir jeg ofte utålmodig etter å komme tilbake til intervjuobjektene når Mohr går inn i lengre analysepassasjer. Bokens styrke er nettopp at man som leser får innblikk i hverdagen og livsverdenen til middelklasserussere, og forstår hvilke valg de har gjort som konsekvens av den politiske utviklingen i Russland.

En annen styrke ved boken er hvordan Mohrs intervjuobjekter forklarer det man kan kalle «Krim-effekten». For mange ble nemlig anneksjonen av Krim et vendepunkt hvor de gikk fra å kritisere til å støtte Putin og dagens russiske regime. Dette utenrikspolitiske grepet har hatt stor påvirkning på opinionen i Russland, og styrket Putins popularitet. Flere av Mohrs intervjuobjekter uttrykker misnøye over Vestens forhold til Russland, og gir vestlig innblanding i Ukraina skylden for konflikten. Slik Putins popularitet på 2000-tallet kunne forklares ved den generelle velstandsøkningen blant befolkningen, ser utenrikspolitikken i dag ut til å ha tatt over som viktigste forklaringsfaktor.

En åpenbar svakhet ved boken, og som Mohr selv også innser på tampen av boken, er at alle hans intervjuobjekter er del av samme generasjon og samme samfunnslag. De er alle middelklasserussere født på 60- og 70-tallet. Jeg skulle gjerne likt å se flere intervjuer med mennesker fra andre samfunnslag, et grep Kalle Kniivilä bruker med hell i Putins folk - Russlands tyste majoritet fra 2014. Russland består som kjent av veldig mye mer enn middelklasse.

Mohr gjør imidlertid et forsøk på å komme denne kritikken i forkjøpet. I bokens nest siste kapittel intervjuer han representanter fra to nære, men distinkte ungdomsgenerasjoner i dagens Russland. Dette er de som er født i 1990 og svært opptatt med å skape sin egen fremtid på mulighetenes marked, og den generasjonen som ikke har noen minner fra 1990-tallets strev (født 1993, 1994) og som stiller spørsmål ved at den eneste presidenten de i praksis har kjent til i sin levetid heter Vladimir Putin. Det var nemlig denne siste generasjonen som tok til gatene i mars og juni 2017 for å protestere mot den omfattende korrupsjonen som hindrer dem i å få den fremtiden de ønsker seg. Det ville vært svært interessant å høre mer fra denne aldersgruppen om hva de tenker, og det blir særs interessant å følge med på om de beholder sin kritiske sans etter hvert som de trer inn i de unge voksnes mer konservative rekker.

Man kan også stille seg spørsmålet om russerne faktisk aktivt stemmer på Putin, slik bokens tittel antyder. For det første kan ikke russiske valg kategoriseres som frie og åpne, og det er grunn til å være kritisk til hvorvidt valgresultatet reflekterer det russiske folkets vilje. For det andre er valgdeltakelsen lav, og statistisk sett vil mange av Mohrs intervjuobjekter rett og slett ikke gå til stemmeurnene ved neste valg våren 2018 . 
Boken er en utmerket introduksjon til en rekke problemstillinger i det politiske systemet i Russland i dag, sett gjennom øynene til dem som opplever det. For den allerede beleste Russlandsinteresserte er det kanskje ikke mye som er nytt, men de personlige historiene giør likevel boken lesverdig. For dem som ikke har egne bekjente i Russland, er boken en mulighet til å få forståelse av hvordan enkeltmennesker opplever og reagerer på utviklingen i Russland. 